\title{
Modeling and Level Estimation of Efficiency of Fiscal Decentralization in Ukraine
}

\author{
Hanna Starostenko \\ Department of Economic Theory \\ National University of the State Fiscal \\ Service of Ukraine \\ Irpin, Ukraine \\ h_star@ukr.net \\ Jan Mrozowski \\ MS Analytics, Ajunct Professor \\ University of Chicago, Benedictine \\ University \\ Chicago, USA \\ yan_xpl@yahoo.com
}

\author{
Iryna Forkun \\ Department of Finance, Banking and \\ Insurance \\ Khmelnytskyi National University \\ Khmelnytskyi, Ukraine \\ ivforkun@gmail.com
}

\author{
Tetyana Gordeeva \\ Department of Finance, Banking and \\ Insurance \\ Khmelnytskyi National University \\ Khmelnytskyi, Ukraine \\ p_gordeeva@khnu.km.ua
}

\begin{abstract}
A priority area for the development of a democratic state is to ensure the well-being of every citizen. Given the current challenges and threats to the Ukrainian economy, achieving these priorities aims at building a domestic budgetary system with an emphasis on ensuring the organizational and financial capacity of local self-government. That is why the issues of fiscal decentralization come to the fore in the context of improving the effectiveness of the implementation of the budgetary policy of Ukraine. The paper considers the problems of implementation of the decentralization reform in Ukraine. The general principles of reform are studied and financial-economic and social results of financial decentralization are analyzed. The conceptual model of an organization of the process of fiscal decentralization is proposed. The estimation of the efficiency of fiscal decentralization in Ukraine is carried out using a set of indicators, such as: the indicator of decentralization by revenues, the indicator of decentralization by expenditures, and generalizing indicator of fiscal decentralization. The results calculated may be used in the decision-making while implementing the reform of fiscal decentralization in Ukraine.
\end{abstract}

Keywords-Fiscal decentralization, budget revenues, budget expenditures, indicators of efficiency, financial potential of local government

\section{INTRODUCTION}

With the proclamation of sovereignty and independence of Ukraine, there's an ongoing work on reforming and improving the State's financial system. Particular attention is paid to reforming the budget system, namely, to ensure financial stabilization at the expense of improving the tax system, increasing the controllability of the regulation process of intergovernmental budget relations, external and internal debt obligations of the State, establishing effective control over the targeted and rational spending of budget funds. The development of the Ukrainian budget system on a market basis actualizes the problem of the distribution of power between the State and local governments in order to ensure the economic efficiency of the provision of public goods and services in the country. One of the ways to increase the level of financial independence of local authorities is decentralization, which envisages legislative regulation of the budgetary autonomy of territorial communities by transferring powers and finances from state authorities to local government level [1].

Basic research in decentralization of public finances belongs to such well-known scientists, as Charles M.Tiebout, Wallace E. Oates and Harvey S. Rosen - they formed the fundamental ideas of fiscal decentralization and defined the obligatory achievement of the effect of social responsibility within it [2]; Richard A. Musgrave has developed the basic principles of fiscal decentralization [3]; M. Bell - defined the scope and purpose of the mandate (fiscal, political, administrative, etc.) in the light of the interactions between the central and subnational (local) governments [4]. There are also considerable scientific works of modern foreign scientists and practitioners, namely: L. Balcerowicz [5], E. Ruśkowski, J. Salachna [6], I. Miklos, M. Jakoby, K. Morvay [7], G. Milbradt [8], Ph. Booth [9], H. Helmut, B. Theilen [10], J.-L. Rocheron[11] etc. These studies fully represent the mechanism of decentralization on the example of post-socialist countries of Europe (Poland, Slovakia, Estonia, and Lithuania) and developed European countries (Sweden, France, Germany, UK, etc.). The experience of foreign countries in organizing and ensuring the process of decentralization emphasizes the success of such a step in providing high-quality and affordable public services to citizens.

Many scholars and practitioners devoted their studies the results of the decentralization reform of funds and authority in Ukraine, for example T. Salo [12], H. Voznyak [13], I. Volokhova [14], L. Demydenko [15], M. Derkach [16], N. Kaminska [17], O. Kyrylenko [18], M. Kulchytskyy [19], I. Lunina [20], I. Chugunov [21], L. Tarangul [22], etc. Highly appreciating the fundamental researches of the scientists, we note that the question of evaluating the effectiveness of fiscal decentralization and identifying the potential for increasing the resource and financial base of local government in providing socio-economic development of the territories and the State, in general, continues to be relevant and this is the unresolved part of the problem under study. Therefore, noted above has broadened the research field, which has determined the relevance of the research of this paper. 


\section{THE RESULTS OF FISCAL DECENTRALIZATION IN UKRAINE}

One of the largest reforms since the independence of Ukraine - the decentralization of government and state finances favoring local government - has been taking place since 2014. The main strategic task of modernizing the system of public administration and territorial organization of authority being implemented in Ukraine today, is the formation of effective local government, creation of comfortable living conditions for citizens, providing them with high-quality and affordable public services. To accomplish these strategic plans will be impossible without the proper level of economic development of the regions of the country, their financial support and sufficient sources of revenues for local budgets. The financial aspect is one of the most important, because most of the success of the functioning of the united territorial communities (UTC) depends upon it.

The effectiveness of the local government involves the qualitative execution of decentralized functions and ensuring the progressive socio-economic development of the territories and should be accompanied by an increase in the resources and funds. These ideas were stated in the "Strategy for innovation and good governance at local level" [23] endorsed by the European Ministers responsible for local and regional government during the Valencia Ministerial Conference in 2007 and adopted by the Committee of Ministers of the Council of Europe on March 2008. The twelve principles of good governance determine the relationship with the population, the effectiveness of the activities and quality of human resources. They are mechanisms, proven by practice, allowing, under the circumstances of the 21st century, avoiding the majority of risks by involving all interested parties (in particular government, business, and the publicity) in the decisionmaking and their further implementation. The foregoing enables to ensure the highest quality and success of management at the local level and to obtain the most effective results during the times of reforms and rapid changes. Ukraine has ratified the European Charter of Local Self-Government [24] and has laid down the constitutional foundations of local self-government.

Adopted on April 1, 2014, the Concept of the Reform of Local Self-Government and Territorial Organization of Government in Ukraine [25] defined the directions, mechanisms and timing of the formation of effective local self-government for creating and maintaining a healthy living environment for citizens, providing high-quality and affordable public services, establishing institutions of direct democracy, meeting the interests of citizens in all spheres of life on the territory of the country, harmonizing the interests of the state and territorial communities. Integration of Ukrainian society into the European community and implementation of the reform of financial decentralization necessitates a profound analysis of its results. At the beginning of 2019, 876 UTCs were created in Ukraine, of which 806 UTCs were functioning. Following approved perspective plans, 1289 UTCs in total should be created. The functioning UTCs include more than 3.7 thousand towns, villages and settlements, or $33.9 \%$ of all territorial communities of the country (excluding occupied territories). Most of the UTC functions in Dnipropetrovsk (62), Cherkassy (54) and Zhytomyr (53) oblasts. The least is in the
Zakarpatska oblast (6), which also is an outsider on the other indicators of the formation of UTC, $21.1 \%$ of the population of Ukraine (without occupied territories) or more than 8.3 million people live in functioning OTCs. Under the area of functioning OTC is $33 \%$ of the entire territory under the control of the Ukrainian authorities, or 189.4 thousand million sq. $\mathrm{km} \mathrm{[1].} \mathrm{Indicators} \mathrm{of} \mathrm{the} \mathrm{execution} \mathrm{of} \mathrm{local}$ budgets reflect the aggregate socio-economic status of the territory and its potential for sustainable development. Statistics shows that, since the beginning of financial decentralization, the flows of own revenues to the general fund of local budgets of Ukraine (revenues without intergovernmental transfers) are growing rapidly: if in 2014, their volume amounted to 68.6 billion UAH, then in 2018 234.1 billion UAH. The absolute growth in 2014-2018 amounted to 165.5 billion UAH, which is 3.4 times. In 2018, compared with 2017 , the own revenues of the general fund of local budgets grew by 41.4 billion UAH or $21.5 \%$ (Fig. 1).

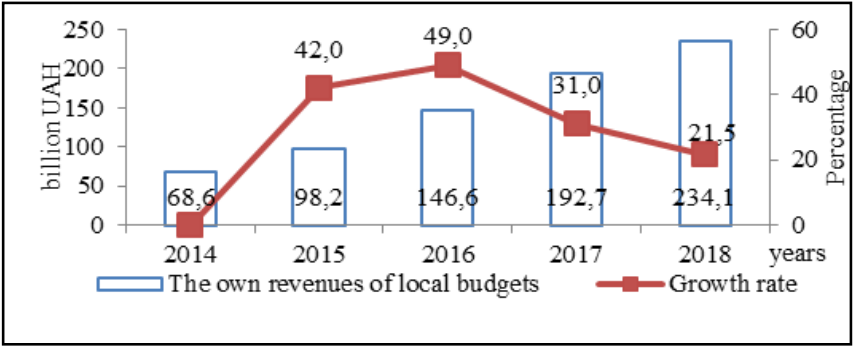

a. Source: compiled by the authors, based on [26]

Fig. 1. Dynamics of own revenues of the general fund of local budgets, UAH billions

Following the results of 2018, the general fund revenues per capita amounted to UAH 6032.9 and increased, compared with 2017 by $21.5 \%$. The amount of personal income tax (PIT) per capita amounted to UAH 3557.9 and increased by $25.5 \%$, local taxes and fees per resident amounted to UAH 1570.6 and increased by $16.1 \%$, respectively. The dynamics of revenues to the budgets of OTCs is ahead of the growth rate of income at other levels of local budgets. In 2018, the local budget revenue of 665 OTCs amounted to 20.9 billion UAH and increased by $62.1 \%$ (plus 8.0 billion UAH). It should be noted that 299 new OTCs, in which the first local elections took place in 2017, received $60 \%$ of income from PIT to their budgets only in 2018, are already showing an increase in their own resources in 2018, compared to the same period in 2017 at 9.7 billion UAH, or 2.7 times (plus 6.2 billion UAH). The growth rate of own revenues of 366 OTCs (formed in 20152016), which in 2017 already received $60 \%$ of the PIT to their budgets, in 2018 is $19.8 \%$ (plus1.8 billion UAH).

The lion's share in own revenues of the general fund of local budgets is the income from PIT $-59 \%$ of the total amount of local budget revenues, or 138.1 billion UAH. In 2018, compared to 2017, the inflow of personal income tax in Ukraine grew by UAH 27.5 billion or by $24.9 \%$. In total, the share of local taxes and fees in the structure of revenues of the general fund of local budgets in 2018 is $26.1 \%$, or 60.9 billion UAH. In all local budgets of Ukraine, the growth of local taxes and fees in 2018, compared to 2017 is $16.1 \%$, and in budgets of oblast significance cities $-12.6 \%$. Income from local taxes and fees in budgets of 665 OTCs grew by $19.4 \%$, which is $3.3 \%$ higher than the average growth rate of local 
budgets in Ukraine. At the end of 2018, the balance of all local budgets of Ukraine on treasury accounts amounted to 49 billion UAH, of which, on the accounts of the general fund -31.8 billion UAH. Particularly, the balances of local budgets of oblast significance cities amounted to 7.7 billion $\mathrm{UAH}$, of which 5.4 billion UAH were in the general fund. The balance of funds on the accounts of UTCs amounted to 5.1 billion UAH, of which on the accounts of the general fund -4.2 billion UAH. Such data show sufficient financial capacity of local budgets of Ukraine. The second part of the revenues of UTCs consists of funds that directly and free of charge transferring in the UTCs' budgets from the state budget as intergovernmental transfers (grants and subventions). These funds are aimed at the development of UTC and financing education, medicine, and social protection. The share of funds transferred from the state budget varies in the range of $65-75 \%$ of total UTCs' revenues. Based on the level of tax revenue of the UTC budget, alongside a similar average for all local budgets of the country, the state budget provides basic and stabilization grants or a reverse grant is transferred to the state budget. Grants are mostly directed to finance the current needs of the local community.

According to the analysis of financial performance of UTCs in 2018, all 665 UTCs are grouped into four groups by the population:

- Group $1-87$ UTCs with a population of more than 15 thousand inhabitants - are least dependent on subsidies from the state budget. The highest level of subsidization is $47.6 \%$.

- Group $2-103$ UTCs with a population of 10 to 15 thousand inhabitants - the highest level of subsidization is $54.8 \%$ (in 3 communities the subsidy rate exceeds $50 \%$ ).

- Group 3-227 UTCs with a population of 5 to 10 thousand inhabitants - the highest level of subsidization is $57.9 \%$ (in 5 communities the subsidy rate exceeds $50 \%$ ).

- Group 4-248 UTCs with a population of fewer than 5 thousand inhabitants - the highest level of subsidization is $60.3 \%$ (in two communities the subsidy rate exceeds $50 \%$ ).

Fig. 2 shows the amount of grants for UTCs in 2018.

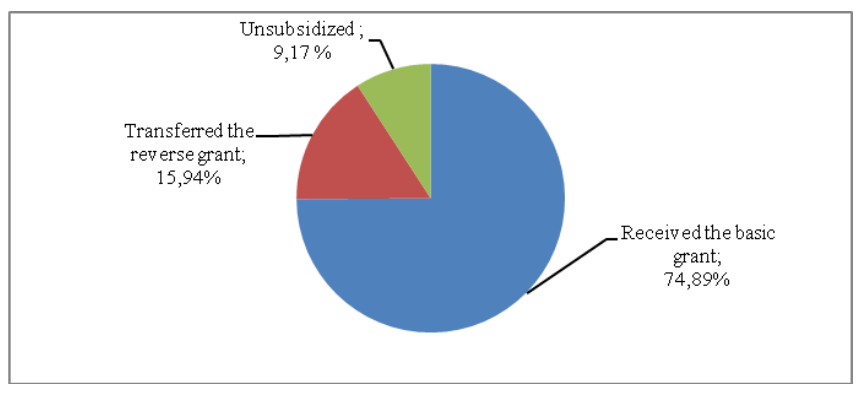

b. Source: compiled by the authors, based on [27]

Fig. 2. The grants for UTCs in $2018, \%$

In total, as Fig. 2 shows, in 2018, 498 UTCs received the basic grant from the state budget, or $74.89 \%$ (every 7 out of 10 UTCs); 106 UTCs not only provided their budgets with own revenues, but also transferred the reverse grant, or $15.94 \%$ (every sixth UTC); 61 UTCs were unsubsidized (neither received nor transferred grants to the state budget), or $9.17 \%$ ( 1 out of 10 UTCs). Furthermore, at the expense of state funds, the amount of budget support to local authorities for community development and infrastructure development has been increased. Namely, if in 2014, in support of socioeconomic development of the regions of Ukraine, only 0.5 billion UAH was aimed from the state budget, then in 2018 the amount of funds for the implementation of infrastructure projects amounted to 19.37 billion UAH, and in 2019 it is planned to spend 20.75 billion UAH, which is 41.5 times more than in 2014. In addition, the State Budget of Ukraine for 2019 provides for a subvention for the construction, reconstruction, repair, and maintenance of roads of general use of local importance of 14.7 billion UAH. The analysis makes it possible to draw preliminary conclusions that, as a result of decentralization reform, local authorities raise their level of interest in increasing revenues to local budgets, finding reserves for their filling, and improving the efficiency of administration of taxes and fees. UTCs provide for creating an efficient and not too numerous administrative apparatus, show high and dynamic growth rates of own revenues, and form the most optimal structure of budget expenditures, conduct a constant analysis of spending budget funds and control the targeted and effective using of them. Thus, the availability of sufficient resources in local budgets is a guarantee that the territorial community can provide better and more diverse services to its inhabitants, to implement social and infrastructure projects, to create conditions for entrepreneurship development, attract investment capital, develop local development programs and finance other measures for a comprehensive improvement of living conditions for community residents.

\section{DESCRIPTION OF PROBLEM}

The decentralization has made significant adjustments to all areas of socio-economic relations. Among the most significant is the impact of the decentralization process on the GDP dynamics (table I).

TABLE I. DYNAMICS OF MACROECONOMIC INDICATORS OF DEVELOPMENT OF UKRAINE IN 2014-2018

\begin{tabular}{|l|c|c|c|c|c|}
\hline \multicolumn{1}{|c|}{ Indicators } & \multicolumn{5}{|c|}{ Years } \\
\cline { 2 - 6 } & $\mathbf{2 0 1 4}$ & $\mathbf{2 0 1 5}$ & $\mathbf{2 0 1 6}$ & $\mathbf{2 0 1 7}$ & $\mathbf{2 0 1 8}$ \\
\hline $\begin{array}{l}\text { Nominal GDP, } \\
\text { billion UAH }\end{array}$ & 1566 & 1979 & 2383 & 2982 & 3558 \\
\hline Growth rate, $\%$ & - & 26.3 & 20.4 & 25.2 & 19.3 \\
\hline $\begin{array}{l}\text { Nominal GDP, } \\
\text { million USA }\end{array}$ & 131805 & 90615 & 93270 & 112154 & 130832 \\
\hline $\begin{array}{l}\text { Real GDP, } \\
\text { billion UAH }\end{array}$ & 1365 & 1430 & 2034 & 2445 & 3083 \\
\hline Growth rate, \% & - & 4.8 & 42.2 & 20.2 & 26.1 \\
\hline $\begin{array}{l}\text { Difference (real } \\
\text { nom.GDP), } \\
\text { billion UAH }\end{array}$ & -201 & -549 & -348 & -537 & -475 \\
\hline $\begin{array}{l}\text { GDP per capita, } \\
\text { UAH per }\end{array}$ & 35834 & 46210 & 55853 & 70224 & 84192 \\
\hline $\begin{array}{l}\text { GDP } \\
\text { capita,USD }\end{array}$ & 3014.6 & 2115.4 & 2185.9 & 2640.3 & 3095.2 \\
\hline Growth rate, \% & - & -29.8 & 3.3 & 20.8 & 17.2 \\
\hline $\begin{array}{l}\text { Population, } \\
\text { thousand people }\end{array}$ & 43722 & 42836 & 42668 & 42477 & 42269 \\
\hline
\end{tabular}

c. Source: compiled by the authors, based on [28],[29] 
Table I shows that in 2014-2018 there were significant changes, when nominal GDP grew at a higher pace than real (for example, in 2015 and 2017). This situation occurs during the inflation and the devaluation of the national currency, the increase in prices for goods and services, and simultaneous reduction of volumes of production, consumption of these goods. As a result, the purchasing power of the population is decreasing, as well as a decline in living standards. In Ukraine, GDP per capita in 2018 was fixed at 3095.2 USD, which is $17.2 \%$ more than in the previous year. Notice that Luxembourg is a leader by GDP per capita (107865.27 USA), which exceeds Ukraine's rate by 35 times. Also, in 2018, the average salary in Ukraine was one of the lowest and amounted to about 270 euros, whereas in the EU countries it exceeded an average of 1500 euros, i.e. more than 5 times higher than in Ukraine. In Poland, for example, the average salary was 850 euros, the Czech Republic - 990 euros, Italy - 1900 euros, Germany - 2300 euros, Ireland 2500 euros. The world leader in this aspect is Switzerland the average salary is 8148 euros, also followed by Norway 7094 euros and Denmark - 6069 euros [30].

Despite significant natural and human potential, positive changes in ensuring state and local government management activities, the introduction of market principles of economic development, implementation of a number of key reforms, including the fiscal decentralization reform, the main macroeconomic indicators of Ukraine's development, especially those that characterize the level and the quality of life of the citizens are quite low, which puts the Ukrainian economy at the lowest levels in the ranking of European countries.

Therefore, there is an urgent need for modeling and level estimation of efficiency of execution of budget policy from the perspective of the implementation of the fiscal decentralization reform in Ukraine as a factor in ensuring macroeconomic stability and security of the state.

\section{RESULTS AND DISCUSSION}

The rational choice of fiscal decentralization parameters requires a scientifically reasonable construction for modeling of the scenarios of reform. In our opinion, the conceptual model of the organization of the process fiscal decentralization should contain 8 steps (Fig. 3).

In case of poor result in the scenario, the contents of the scenario parameters should be revised or the expected effect of the modeling should be reduced.

We've proposed to estimate the efficiency of fiscal decentralization within budget policy implementation by a system of indicators of economic, social and organizational efficiency.

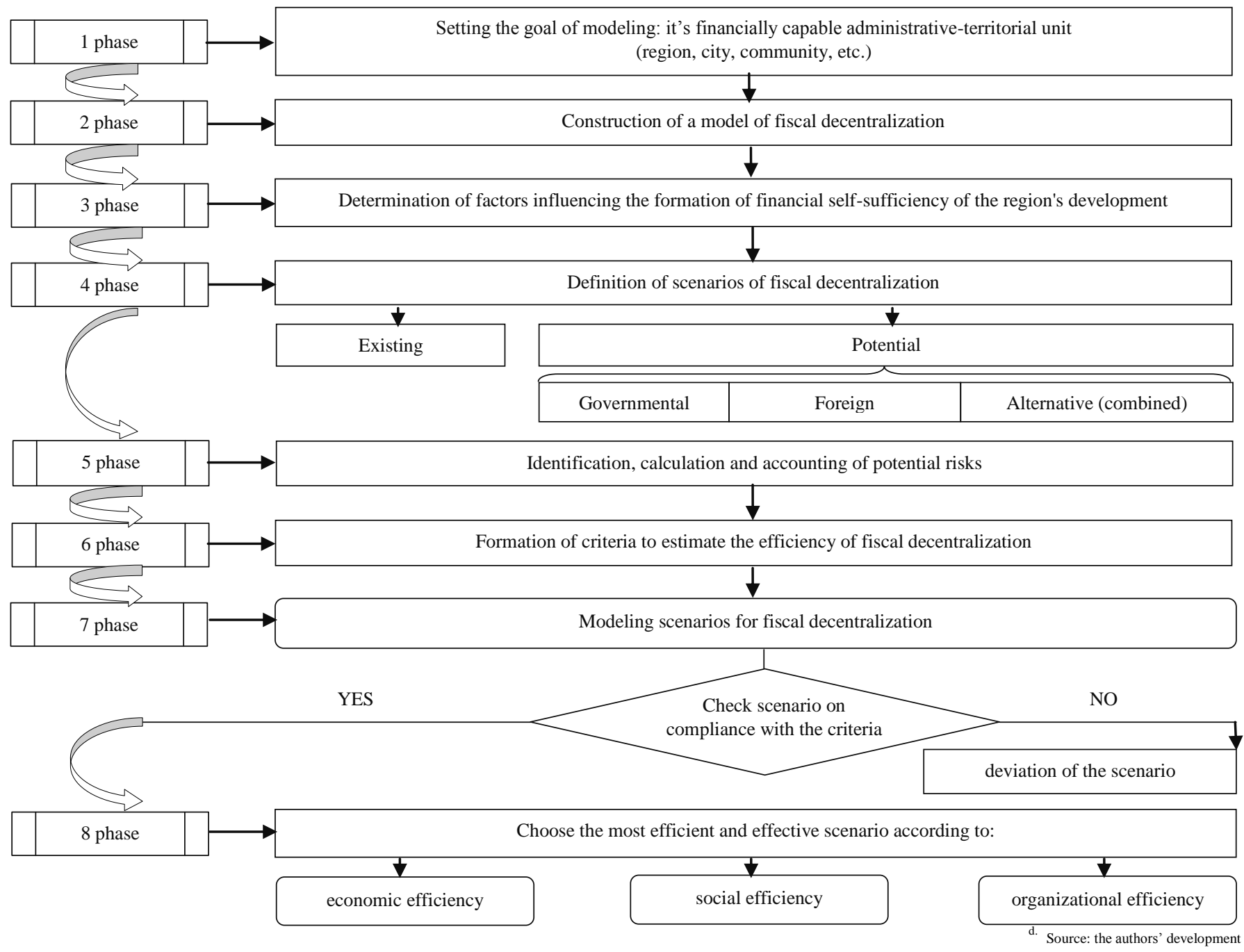

Fig. 3. Conceptual model of the organization of the process of fiscal decentralization 
Social efficiency involves raising the level of employment of the population by: creating new jobs and ensuring wages at the level of European and world indicators; development of the network and raising the level of efficiency of the activity and quality of service in the institutions of socio-cultural sphere and spiritual development; increase the level of social protection of the population, promote the provision of social assistance, services and benefits based on accessibility and quality. Organizational efficiency of fiscal decentralization is achieved in the conditions of high-quality legislative, informational and personnel support, combined with the creation of favorable working conditions and constant monitoring and control of the results of activity in all power structures (including overcoming corruption and misuse of all kinds of resources). The economic efficiency of fiscal decentralization in Ukraine is estimated using indicators of decentralization of incomes, decentralization of expenditures, generalizing indicator of fiscal decentralization.

The calculation of these indicators is carried out without regarding the volumes of intergovernmental transfers according to the formulas (1), (2) and (3) [12]:

- The indicator of fiscal decentralization by revenues $\left(I D_{R}\right)$ :

$$
I D_{R}=\left(R_{L B} / R_{C B}\right) 100 \% \text {, }
$$

Where, $R_{L B}$ - the revenues of local budgets for the relevant year; $R_{C B}$ - the revenues of the consolidated budget for the relevant year.

The optimum value of the indicator of fiscal decentralization by revenues varies depending on the level of development of the state within $35-50 \%$ (more than $50 \%$ in highly developed countries).

- The indicator of fiscal decentralization by expenditures $\left(I D_{E}\right)$ :

$$
I D_{E}=\left(E_{L B} / E_{C B}\right) 100 \% \text {, }
$$

Where, $E_{L B}$ - the expenditures of local budgets for the relevant year; $E_{C B}$ - the expenditures of the consolidated budget for the relevant year.

The optimum value of the indicator of fiscal decentralization by expenditures varies depending on the level of development of the state within $25-45 \%$ (more than $50 \%$ in highly developed countries).

- The generalizing indicator of fiscal decentralization $\left(I D_{G E N}\right)$ :

$$
I D_{G E N}=\left(I D_{R}+I D_{C B}\right) / 2 \text {. }
$$

The optimal value of the generalizing indicator of fiscal decentralization varies depending on the level of development of the state within $30-50 \%$ (more than $50 \%$ in highly developed countries).The indicators of the level of fiscal decentralization in Ukraine calculated according to the data for 2014-2018, is presented in the table II.
TABLE II. LEVEL ESTIMATION OF FISCAL DECENTRALIZATION OF UKRAINE IN 2014-2018

\begin{tabular}{|l|c|c|c|c|c|}
\hline \multicolumn{1}{|c|}{ Indicators } & \multicolumn{4}{|c|}{ Years } \\
\cline { 2 - 6 } & 2014 & 2015 & 2016 & 2017 & 2018 \\
\hline $\begin{array}{l}\text { The Consolidated } \\
\text { budget revenues, } \\
\text { billion UAH }\end{array}$ & 456.1 & 652.0 & 782.9 & 1057.0 & 1184.3 \\
\hline $\begin{array}{l}\text { The revenues of } \\
\text { local budgets, } \\
\text { billion UAH }\end{array}$ & 101.1 & 120.5 & 170.7 & 229.5 & 264.3 \\
\hline $\begin{array}{l}\text { Transfers from the } \\
\text { State budget }\end{array}$ & 130.6 & 174.0 & 195.4 & 272.6 & 304.7 \\
\hline $\begin{array}{l}\text { The Consolidated } \\
\text { budget } \\
\text { expenditures, } \\
\text { billion UAH }\end{array}$ & 523.0 & 679.9 & 835.8 & 1057.0 & 1250.2 \\
\hline $\begin{array}{l}\text { The expenditures } \\
\text { of local budgets, } \\
E_{L B, \text { billion UAH }}\end{array}$ & 233.5 & 277.0 & 346.3 & 490.1 & 567.5 \\
\hline $\begin{array}{l}\text { Transfers into the } \\
\text { State budget }\end{array}$ & 2.1 & 3.1 & 3.4 & 5.7 & 7.4 \\
\hline $\begin{array}{l}\text { The indicator of } \\
\text { fiscal } \\
\text { decentralization by } \\
\text { revenues }\left(I D_{R}\right)\end{array}$ & 22.2 & 18.5 & 21.8 & 21.7 & 22.3 \\
\hline $\begin{array}{l}\text { The indicator of } \\
\text { fiscal } \\
\text { decentralization by } \\
\text { expenditures (IDE }\end{array}$ & 44.6 & 40.7 & 41.4 & 46.4 & 45.4 \\
\hline $\begin{array}{l}\text { The generalizing } \\
\text { indicator of fiscal } \\
\text { decentralization } \\
\left(I D_{G E N}\right)\end{array}$ & 33.4 & 29.6 & 31.6 & 34.0 & 7.4 \\
\hline $\begin{array}{l}\text { Level of GDP } \\
\text { redistribution } \\
\text { through } \\
\text { budgets, \% }\end{array}$ & 6.5 & 6.1 & 7.2 & 7.7 & \\
\hline
\end{tabular}

e. Source: compiled by the authors, based on [26], [27], [28]

Indicators for the estimation of the economic efficiency of fiscal decentralization, as calculated in table II, clearly demonstrate the established tendency of centralizing the budget system of Ukraine both in revenues and expenditures. The state revenues are more centralized than expenditures. The volumes of intergovernmental transfers from the state budget exceed own revenues of local budgets. Therefore, in 2014-2018, the indicators of decentralization of incomes and expenditures almost did not change in dynamics, which corresponds to the aggressive contradiction with the declared provisions of the Concept of decentralization. The generalizing indicator of fiscal decentralization fluctuates within 30-34\%, which corresponds to the lower limit of this parameter, thus characterizes the low economic development of the State, and the complexity of the practice of implementing reforms in Ukraine, including reform of decentralization. The assessment of the level of GDP redistribution through local budgets has shown that it increases from $6.5 \%$ in 2014 to $7.4 \%$ in 2018 (Fig. 4).

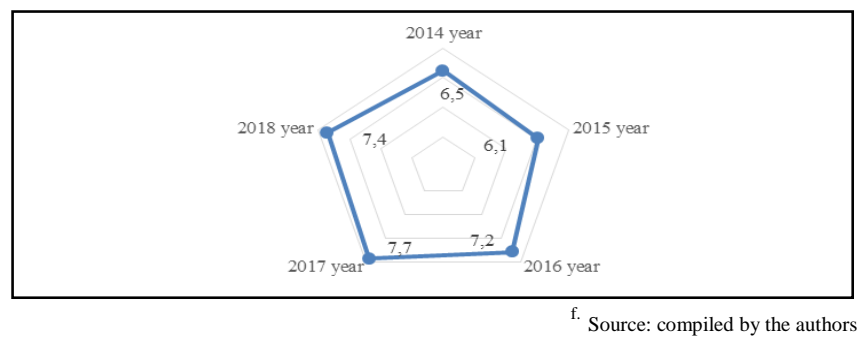

Fig. 4. Level of GDP redistribution through local budgets, $\%$ 
The volatility of this indicator is due to the instability of Ukraine's economic development, and its level indicates a low level of financial autonomy of local budgets, which adversely affects the development of administrativeterritorial communities.

\section{CONCLUSION}

The study of the results of fiscal decentralization reform in Ukrainian and world practice makes it possible to state that its concept and results have unquestionably positive effects. Namely, local budget revenues are increasing, which enables local governments to increase budget financing for economic and social activities. This, in turn, ensures both the socio-economic development of the UTC and the well-being of every citizen through GDP per capita growth. However, the imperfection of the legislation, the lack of financial resources at the disposal of the OTCs, the tendency of their centralization from the State, lack of skilled personnel, migration of the inhabitants of the OTCs beyond their borders, unofficial employment, low activity of residents in addressing the issues of community functioning - all of it has a negative impact on efficiency carrying out this reform. This is evidenced by the generalized indicator of fiscal decentralization, which in the period under review retains the established value. The financial efficiency of the decentralization reform is one of the most important components, since organizational and social components depend on its results and, thus, the success of the OTGs, the regions and the state as a whole. The use of the obtained scientific results in the practical activity of local selfgovernment, namely the proposed conceptual model of organization of the process of fiscal decentralization with the emphasis on conducting a continuous estimation of the efficiency of decentralization by certain indicators should become one of the basic components of making effective management decisions in the direction of successful development of UTCs. Only under such conditions is it possible to ensure the rapid development of the economy of Ukraine and its regions and achieve European standards of economic development and ensure a high level and quality of life for citizens. Further research by the team of authors will be aimed at expanding the system of indicators for level estimation of efficiency of decentralization and building an integral indicator.

\section{REFERENCES}

[1] Decentralization [Online]. Available: https://decentralization.gov.ua/. Accessed on: Jun.24,2019.

[2] C.M.Tiebout, "An Economic Theory of Fiscal Decentralization", NBER Chapters, in Public Finances: Needs, Sources, and Utilization, Princeton, USA: Univ.Press, 1961, pp. 79-96

[3] Musgrave, R.A. The Theory of Public Finance - A Study in Public Economy. New York: McGraw-Hill, 1959

[4] M.Bell, and C.Adams, "Fiscal Decentralization Indicators: Local Democratic Governance", in Proc. 92nd Annu.Conf. of National Tax Association, Atlanta,.1999, pp. 236-241

[5] L.Balcerowicz Freedom, development, democracy. Warsaw: Publ Red and Black, 2017.

[6] E.Ruśkowski, and J.Salachna, Local finance after accession. Warsaw: Wolters Kluwer Polska Sp., 2015

[7] I. Miklos, M Jakoby, and K Morvay, "Tax Reform in the Slovak Republic", in CESifo DICE Report, München, vol.3, iss. 3, 2005, pp.53-60.

[8] G. Milbradt, "Advantages of the decentralized distribution of tasks German cooperation”, in Proc.Conf., Kyiv,.2014. [Online]. Available:
http://gogov.org.ua/wp-content/uploads/2016/05/Vorteile-derdezentralisierten-Aufgabenverteilung-Prof.-Dr.-Georg-MilbradtMinisterpr-sident-a.D.-des-Freistaates-Sachsen.pdf. Accessed on: Jun.24,2019.

[9] Ph.Booth, Federal Britain. The Case for Decentralisation London: IEA, 2015 (interactive PDF) [Online]. Available: https://iea.org.uk/wp-content/uploads/2016/07/Booth-Federal-BritainInteractive.pdf. Accessed on: Jun.24,2019.

[10] H. Helmut, B.Theilen "Fiscal Decentralization and Public Spending: Evidence from Heteroscedasticity-Based Identification". In The B.E. Journal of Economic Analysis \& Policy, vol. 17, iss. 2, Apr, 2017

[11] J.-L. Rocheron The French Experience of Decentralization. Administrateurs Territoriauksz. Jan. 2016 (interactive PDF) [Online]. Available: https://www.arricod.fr/wp-content/uploads/The-FrenchExperience-of-Decentralization.pdf. Accessed on: Jun.24,2019.

[12] T.Salo, "Decentralization of financial system: status and evaluation of its level in Ukraine", in Efficiency of public administration. iss.35, 2013, pp.324-330

[13] H.Voznyak, "Fiscal decentralization: European experience and perspectives foe Ukraine", Socio-economic problems of the modern period of Ukraine, no.3, pp.56-62, 2016.

[14] I. Volokhova, Local finances and prospects development of financial decentralization in Ukraine. Odessa, Ukraine: Atlant, 2014.

[15] L. Demydenko, and Y.Nakonechna, "Fiscal decentralization: the experience of Germany and the realities of Ukraine", Bulletin of Taras Shevchenko National University of Kyiv. Economics, vol.26(167), pp 49-55, 2015.

[16] M. Derkach, Decentralization of fiscal functions of the State in the context of ensuring sustainable development of Ukraine. Dnipro, Ukraine: Goncharov National University, 2011.

[17] N. Kaminska, "Decentralization of power and experience it in foreign countries", Scientific Papers of the Legislation Institute of the Verkhovna Rada of Ukraine, vol.4, pp.35-40, 2014.

[18] O.Kyrylenko, and O.Maksymchuk, "Capital investments from local budgets: modern practice and prospects for improvement", Investytsiyi: praktyka ta dosvid, vol.2, pp.5-12, 2019

[19] M.Kulchytskyy,and O.Zabrotska, "Decentralization as a basis for development of regions and improving the financial security of territories", Business Inform, no.4, pp.88-95, 2016.

[20] I.Lunina, "Fiscal decentralization: the goals and directions of reforms", Economy of Ukraine, no.11,pp.61-75, 2014.

[21] I Chugunov, and $\mathrm{K}$ Bryzhan, "Budget policy in the context of transforming the economy", University Economic Bulletin, no.32/1, pp.241-251, 2017.

[22] L.Tarangul, and M. Khomyak, "Institutional aspects of distribution of state revenue in framework of budget space of regions", Economy of Industry, no. 1(77), pp.38-50, 2017.

[23] Strategy of Innovation and Good Governance at Local Level. European Committee on Local and Regional Democracy, Strasbourg, 6 september 2011 [Online]. Available: https://rm.coe.int/1680746d1d. Accessed on: Jun.24,2019.

[24] The Council of Europe (1985,Oct. 15) European Charter of Local Self-Government [Online]

Available: https://www.coe.int/en/web/conventions/full-list//conventions/treaty/122. Accessed on: Jun.24,2019.

[25] Cabinet of Ministers of Ukraine (2014, Apr.1) Concept of the Reform of Local Self-Government and Territorial Organization of Government in Ukraine [Online]. Available: https://zakon.rada.gov.ua/laws/show/333-2014-\%D1\%80. Accessed on: Jun.24,2019.

[26] Official website of Ministry of Finance of Ukraine. [Online]. Available: https://www.minfin.gov.ua. Accessed on: Jun.24,2019.

[27] Official website of the State Treasury Service of Ukraine [Online]. Available: /www.treasury.gov.ua. Accessed on: Jun.24,2019.

[28] Official website of the State Statistic Service of Ukraine [Online]. Available: http://www.ukrstat.gov.ua/. Accessed on: Jun.24,2019.

[29] Official website of The World Bank [Online]. Available: https://www.worldbank.org/. Accessed on: Jun.24,2019.

[30] Official website of Eurostat [Online]. Available: https://ec.europa.eu/eurostat/web/main/home. Accessed on: Jun.24,2019. 